\title{
Soil Fertility Management in Westsik's Crop Rotation Experiment
}

\author{
Janos Lazanyi \\ University of Debrecen, Centre of Agricultural Sciences, \\ Institute of Agricultural Economics and Rural Development, \\ Department of Rural Development and Resource Management, \\ Debrecen
}

\section{SUMMARY}

The crop rotation experiment, established by Vilmos Westsik in 1929, is the best known and most remarkable example of continuous production in Hungary. It is still used to study the effects of organic manure treatment, develop models and predict the likely effects of different cropping systems on soil properties and crop yields. Westsik's crop rotation experiment provides data of immediate value to farmers concerning the applications of fertilisers, green, straw and farmyard manure. The experiment also provides a resource of yield, plant and soil data sets for scientific research into the soil and plant processes which control soil fertility, and into the sustainability of production without environmental deterioration. The maintenance of Westsik's crop rotation experiment can be used to illustrate the value of long-term field experiments.

\section{INTRODUCTION}

Developing an appropriate crop rotation scheme is one of the most challenging tasks in putting a sustainable system together. Farmers should develop a rotation with both the needs of the farm and the needs of the ecosystem in mind. Farm requirement includes such considerations as a market for the crops in the rotation, suitability to the soil, ecological condition, equipment requirements, on-farm feed and cash flow needs (Lockeretz, 1988; Lazanyi, 1997b). Sustainable crop rotation should provide effective weed control by (i) alternating between cold and hot weather plants, (ii) including plants adapted to mechanical weed control, or with (iii) allelopathic properties, including (iv) leguminous crops and (v) crop with fibrous root systems to improve soil structure. Crop rotation breaks the weed and insect cycles that often predominate in continuous cropping and provides effective insect and disease control. Crop rotation also enhances soil structure and improves water regime. This way, leguminous crops have long term benefits, resulting in enhanced soil organic matter content, which not only improves nitrogen availability but also improves soil structure by reducing soil erosion and cultivation costs (Lazanyi, 1995b; Pepo and Nagy, 1997; Varallyay 1989).

There is also evidence suggesting that an improved soil structure increases biological activity in the soil and enables plants to utilise soil moisture and nutrients more effectively. Crop rotation can also contribute to soil conservation strategy by including leguminous crop in the rotation (Lazanyi, 1998c). The beneficial effect of specific crops on the yield of subsequent crops was already known in ancient

times. Changes in the economics of crop production and recognition of the potential environmentally damaging effects of agricultural chemicals have led to renewed interest in organic production systems, which are able to replace the purchased inputs with cultural practices involving crop rotation (Lazanyi, 1995a). Although research continues into how crop rotation influences subsequent crop yields, farmers can receive maximum benefits from rotating crops if they know the conditions which influence rotation effects.

The correct planning of crop rotations is a basic issue in sustainable farming because it offers an opportunity to increase yields through better organisation and more efficient utilisation of the available biological and economic resources without extra costs (Fuleki, 1997; Gyorffy, 1975; Lazanyi, 1994, 1998a). It has to be noted, though, that crop rotation can only be successful if it strives for the maintenance and development of soil fertility. The poorer the natural nutrient supplying capacity of the soil is and the more extreme ecological conditions have to be met at the planning of the crop rotation, the more emphasis must be laid on the improvement of soil fertility so that the yield standards could be ensured even in the long run (Lazanyi, 1996, 1999b).

\section{TREATMENTS IN WESTSIK'S CROP ROTATION EXPERIMENT}

Crop rotation F-1 models the traditional farming practice, which was widely used in the Nyírség region even at the beginning of the $20^{\text {th }}$ century. Vilmos Westsik included this crop rotation in the experiment as a control treatment. This three-course crop rotation involves potato and rye production and also green fallow. The rationale behind this rotation, generally accepted at the turn of the century, should be found not only in the economic regulations but also in animal husbandry practices (Lazanyi, 1998b).

The Nyírség region was short of adequate pastures and farmers were driven to leave a small proportion of their lands uncultivated and have it grazed by farm animals. This type of fallow combined with grazing is a version of the crop rotation practised in the Kunság region, further developed, and adapted to sandy soils in the Nyírség. Simple fallow would have increased the danger of wind erosion; but simultaneous grazing on fallow lands saved the area from the proliferation of weeds (Lazanyi, 1998d).

Earlier, Vilmos Westsik had already called attention to the economic problems of fallow entirely 
lacking nutrient management (Westsik, 1951). One of the most important aims of starting the crop rotation experiment was the development of a system, which could replace fallow, so widely used earlier, as it would be in better accordance with the changing conditions of agriculture. To achieve this goal, experiments with (i) straw manure, (ii) green manure from main or second crop lupine and (iii) the production of green fodder crops were carried out.

Each treatment was aimed at the study of the more efficient utilisation of fallow fields (Westsik, 1965). In addition, they served more efficient nutrient management and an improved supply of green forage for the farms. Planting various grasslands or developing and maintaining crop rotations with grasses would have been a method inducing excessively high nutrient demands on unfavourable soils and under the dry weather conditions of the Nyírség region.

The treatments of Westsik's crop rotation experiment were intended to increase soil organic matter and fertility by different organic matter amendments as the original purpose was to evaluate the cumulative effects of organic matters on light, poorly structured sandy soil with a long history of arable cropping (Lazanyi, 1997a, 1999a).

The F-1 block received no fertilisers and organic material treatment except the rye and potato roots and straw incorporated into the soil. The fallow in this block was green and the plant material produced was incorporated into the soil. The F-2 block represents green manure treatment, where lupine was grown as a main crop and ploughed into the soil 4-5 weeks after flowering. The phosphorus and potassium fertilisers in this treatment were applied the previous autumn before the lupines were sown. F3 represents lupine root manure treatment, where lupine was grown for grain and the total organic matter, except for the grain, was incorporated into the soil.

Blocks F-4 - F-7 represent straw manure treatments. In the F-4 block, rye straw was applied as mulch. In blocks F-6 and F-7 straw manure was fermented without nitrogen and in block F-6 with nitrogen addition. The straw manure was incorporated into the soil 4-6 weeks before the sowing of rye. F-8 is the only 4 -year crop rotation block where lupine grew 2 times in 4 years; once as a main crop produced for grain and once as a second crop produced after rye and before potato, for green manure. In the F-9 block, lupine was grown as a forage crop and harvested 2-3 weeks after flowering. Blocks F-10 and F-11 represent farmyard manure treatments without and with supplementary fertilisers.

In block F-12, lupine is grown after a green forage crop and sown in May. This block is also evaluated with farmyard manure treatments to measure the comparative effects of the two treatments. Blocks F-13 - F-15 represent green manure treatments, where lupine is grown as a second crop after rye and before potato. The F-15 block received no supplementary fertilisers. The difference between blocks F-13 and F-14 is apparent at the time of the incorporation of green manure (Table 1).

Table 1: Treatments and Total Fertilizer Inputs in Westsik's Crop Rotation Experiment

\begin{tabular}{|c|c|c|c|c|c|c|c|c|}
\hline \multirow{2}{*}{\multicolumn{2}{|c|}{ Organic Matter Treatments }} & \multirow{2}{*}{ t/ha } & \multirow{2}{*}{ 1. Crop } & \multirow{2}{*}{ 2. Crop } & \multirow{2}{*}{ 3. Crop } & $\mathbf{N}$ & $\mathbf{P}$ & $\mathbf{K}$ \\
\hline & & & & & & \multicolumn{3}{|c|}{ kg/ha/3 (4) years } \\
\hline $\mathrm{F}-1$ & Fallow & NM & Fallow $=$ & Rye & Potato & & & \\
\hline $\mathrm{F}-2$ & Green manure & NM & Lupine $=$ & Rye & Potato & 43 & 94 & 84 \\
\hline F-3 & Root manure & NM & Lupine $=$ & Rye & Potato & 43 & 94 & 84 \\
\hline $\mathrm{F}-4$ & Mulch & 3.48 & Rye + & Potato & Rye & 104 & 94 & 84 \\
\hline $\mathrm{F}-5$ & Straw manure & 11.3 & Rye+ + & Potato & Rye & 104 & 94 & 84 \\
\hline F-6 & Straw manure & 26.1 & Rye + & Potato & Rye & 104 & 94 & 84 \\
\hline $\mathrm{F}-7$ & Straw manure & 26.1 & Rye + & Potato & Rye & & & \\
\hline F-8 & Green manure & NM & Lupine $=$ & Rye+ + & Potato & 86 & 94 & 84 \\
\hline F-9 & Green forage & NM & Lupine $=$ & Rye & Potato & 86 & 94 & 84 \\
\hline $\mathrm{F}-10$ & Farmyard manure & 26.1 & +Forage & Rye & Potato & & & \\
\hline F-11 & Farmyard manure & 26.1 & +Forage & Rye & Potato & 43 & 94 & 84 \\
\hline $\mathrm{F}-12$ & Green manure second crop & NM & Rye+ + & Rye & Potato & 43 & 94 & 84 \\
\hline $\mathrm{F}-13$ & Green manure second crop & NM & Rye+ & Potato & Rye & 86 & 93 & 84 \\
\hline $\mathrm{F}-14$ & Green manure second crop & NM & Rye + & Potato & Rye & 86 & 93 & 84 \\
\hline F-15 & Green manure second crop & NM & Rye+ + & Potato & Rye & & & \\
\hline
\end{tabular}

$\mathrm{NM}=$ not measured; Crop 4 in F-8 treatment is rye 


\section{RESULTS}

Westsik's crop rotation experiment is a logical successor to, and an extension of, the farmyard and green manure experiments established in Hungary. The major differences from previous experiments are as follows:

- The experiment is set up with strict crop rotation where rye and potato are grown at least once in every 3 years.

- Fertilisers, organic manure (farmyard, straw and green manure) are applied cumulatively for many years.
- The value of fertilisers and organic manure can be compared with control plot (fallow) and plots all gave similar amount of organic manure each year.

- The design of the experiments allows residues of organic matter from previous treatments to be evaluated.

- The value of organic matter applied for many years can be compared with effects nitrogen, phosphorus and potassium fertilisers.

Response of potato and rye to organic manure treatments is summarised in Table 2. Statistical analysis can be found in Table 3 and 4.

Table 2: Means and Differences from Main Average of Yield in Westsik's Crop Rotation Experiment

\begin{tabular}{|c|c|c|c|c|c|c|c|c|c|c|c|c|c|c|c|}
\hline Yea & -1 & F-2 & F-3 & F-4 & F-5 & F-6 & F-7 & F-8 & F-9 & F-10 & F-11 & F-12 & F-13 & F-14 & F-15 \\
\hline \multicolumn{16}{|c|}{ erage of yield $=2.06 \mathrm{t} / \mathrm{ha}$ ) } \\
\hline 193 & 99 & .73 & 5 & 1.59 & 1.88 & ${ }^{4}$ & 1.39 & 2.14 & 1.96 & 90 & 2 & 1 & 2 & 0 & .62 \\
\hline & 0.81 & 1 & 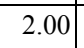 & 1.82 & 1.97 & 2.22 & 1.34 & 2.71 & 2.48 & 1.78 & 2.53 & .38 & 19 & 07 & 41 \\
\hline & & & & 2.31 & 2 & 2.83 & 1 & 3.13 & 2.95 & 34 & 2.81 & 2.53 & 2.51 & 2.57 & 12 \\
\hline & & & 2.17 & 37 & 2 & 2.31 & 1.35 & 2.62 & 2.43 & .01 & . & $4 \mathrm{~J}$ & 20 & 10 & 1.35 \\
\hline & & 2.5 & 4 & 2.8 & -8.7 & -1.0 & -32.5 & 3.9 & -4.9 & -5.3 & 12.6 & 6.7 & -6.8 & -7.8 & -21.4 \\
\hline & 0.7 & 16.0 & -2.9 & -11.7 & -4.4 & 7.8 & -35.0 & 31.6 & 20.4 & -13.6 & 22.8 & 15.5 & 6.3 & 0.5 & -31.6 \\
\hline & & 11.7 & 15.5 & 12.1 & 22.3 & 37.4 & -33.0 & 51.9 & 43.2 & 13.6 & 36.4 & 22.8 & 21.8 & 24.8 & -41.3 \\
\hline $1931-99(\%$ & -54.9 & 18.4 & 5.3 & -9.2 & 1.0 & 12.1 & -34.5 & 27.2 & 18.0 & -2.4 & 21.4 & 18.9 & 6.8 & 5.8 & -34.5 \\
\hline \multicolumn{16}{|c|}{ Potato (main average of yield $=9.56 \mathrm{t} / \mathrm{ha}$ ) } \\
\hline $931-$ & 4.49 & 9.71 & 7.72 & 8.23 & 9.16 & 10.79 & 8.11 & 11.38 & 8.10 & 9.68 & 9.30 & 10.92 & 12.56 & 11.31 & 9.56 \\
\hline 1952-72 (t/ha) & 3.67 & 10 & 8.70 & 8.05 & 9.27 & 10.72 & 7.49 & 12.04 & 9.58 & 9.21 & 11.94 & 11.08 & 9.62 & 9.15 & 7.53 \\
\hline 1973-93 (t/ha) & 4.13 & 7.53 & 1 & 9.64 & 11.19 & 10.11 & 7.66 & 13.4 & 8.97 & 10.37 & 13.81 & 11.01 & 9.27 & 0.44 & 6. \\
\hline $1931-99$ (t/ha) & 4.33 & 8.62 & 8.06 & 8.76 & 9.89 & 11.72 & 7.90 & 12.53 & 9.22 & 10.13 & 11.97 & 11.39 & 10.86 & 10.46 & 7.94 \\
\hline 31. & 3.0 & 16 & \begin{tabular}{|c|}
-19.2 \\
\end{tabular} & -13.9 & -4.1 & 12.9 & -15.1 & 19.1 & $\begin{array}{ll}-15.2 \\
\end{array}$ & 1.3 & -2.7 & 14.3 & 31.4 & 18.4 & 0.0 \\
\hline $52-$ & \begin{tabular}{|c|}
-61.6 \\
\end{tabular} & -4.8 & -9.0 & -15.8 & -3.0 & 12.2 & \begin{tabular}{|c|}
-21.6 \\
\end{tabular} & 26.0 & 0.3 & \begin{tabular}{ll|}
-3.6 \\
\end{tabular} & 25.0 & 16.0 & 0.7 & -4.2 & -21.2 \\
\hline $1973-93(\%$ & \begin{tabular}{|c|}
-56.8 \\
\end{tabular} & 1.2 & \begin{tabular}{|c|}
-21.8 \\
\end{tabular} & 0.9 & 17.1 & 37.2 & \begin{tabular}{|l|}
-19.8 \\
\end{tabular} & 40.3 & -6.1 & 8.5 & 44.5 & 24.2 & -3.0 & 9.3 & -34.6 \\
\hline 931-99 (\%) & 4.7 & -9.8 & -15.7 & -8.3 & 3.5 & 22.6 & \begin{tabular}{|c|}
-17.3 \\
\end{tabular} & 31 & -3.5 & 6.1 & 25.3 & 19.2 & 13.6 & 9.5 & -16.9 \\
\hline
\end{tabular}

Table 3: Statistical analysis of rye yield in Westsik crop rotation experiment

SPSS, General linear model, Repeated measure (1931-2000)

\begin{tabular}{|l|l|l|l|l|l|l|l|}
\hline \multirow{2}{*}{$\begin{array}{c}\text { Crop } \\
\text { rota- } \\
\text { tion }\end{array}$} & $\mathbf{1}$ & $\mathbf{2}$ & $\mathbf{3}$ & $\mathbf{4}$ & $\mathbf{5}$ & $\mathbf{6}$ & $\mathbf{7}$ \\
\hline & Rye yield (t/ha) in different group of significance \\
\hline F-1 & 0.927 & & & & & & \\
\hline F-15 & & 1.342 & & & & & \\
\hline F-7 & & 1.357 & & & & & \\
\hline F-4 & & & 1.860 & & & & \\
\hline F-10 & & & 2.010 & 2.010 & & & \\
\hline F-5 & & & 2.077 & 2.077 & 2.077 & & \\
\hline F-3 & & & 2.160 & 2.160 & 2.160 & 2.160 & \\
\hline F-14 & & & 2.177 & 2.177 & 2.177 & 2.177 & \\
\hline F-13 & & & 2.194 & 2.194 & 2.194 & 2.194 & \\
\hline F-6 & & & & 2.318 & 2.318 & 2.318 & 2.318 \\
\hline F-2 & & & & & 2.427 & 2.427 & 2.427 \\
\hline F-12 & & & & & 2.429 & 2.429 & 2.429 \\
\hline F-9 & & & & & 2.430 & 2.430 & 2.430 \\
\hline F-11 & & & & & & 2.501 & 2.501 \\
\hline F-8 & & & & & & & 2.622 \\
\hline Sign. & 1.000 & 1.000 & 0.122 & 0.223 & 0.074 & 0.102 & 0.236 \\
\hline
\end{tabular}

Table 4: Statistical analysis of potato yield in Westsik crop rotation experiment

SPSS, General linear model, Repeated measure (1931-2000)

\begin{tabular}{|l|c|c|c|c|c|c|}
\hline \multirow{2}{*}{$\begin{array}{c}\text { Crop } \\
\text { rota- } \\
\text { tion }\end{array}$} & $\mathbf{1}$ & $\mathbf{2}$ & $\mathbf{3}$ & $\mathbf{4}$ & $\mathbf{5}$ & $\mathbf{6}$ \\
\hline & Potato yield (t/ha) in different group of significance \\
\hline F-1 & 4.348 & & & & & \\
\hline F-7 & & 7.906 & & & & \\
\hline F-15 & & 7.964 & 7.964 & & & \\
\hline F-3 & & 8.047 & 8.047 & & & \\
\hline F-2 & & 8.737 & 8.737 & 8.737 & & \\
\hline F-4 & & 8.784 & 8.784 & 8.784 & & \\
\hline F-9 & & 9.281 & 9.281 & 9.281 & 9.281 & \\
\hline F-5 & & 9.979 & 9.979 & 9.979 & 9.979 & 9.979 \\
\hline F-10 & & 10.179 & 10.179 & 10.179 & 10.179 & 10.179 \\
\hline F-14 & & 10.538 & 10.538 & 10.538 & 10.538 & 10.538 \\
\hline F-13 & & & 10.887 & 10.887 & 10.887 & 10.887 \\
\hline F-12 & & & & 11.465 & 11.465 & 11.465 \\
\hline F-6 & & & & & 11.767 & 11.767 \\
\hline F-11 & & & & & 12.096 & 12.096 \\
\hline F-8 & & & & & & 12.608 \\
\hline Sign. & 1.000 & 0.140 & 0.053 & 0.104 & 0.078 & 0.141 \\
\hline
\end{tabular}


Control treatments: In treatment $\mathrm{F}-1$, rye was grown after green fallow. In treatment F-7 rye followed rye and received $3.48 \mathrm{t} / \mathrm{ha}$ fermented straw manure. In treatment F-10, rye was sown after forage crop which received $26.1 \mathrm{t} / \mathrm{ha}$ farmyard manure. In treatment F-15, potato followed rye and lupine green manure second crop green manure was sown before potato. In the control treatments, rye yields lagged behind the average of the other treatments by 5.3$60.7 \%$. The greatest yield reduction could be observed in F-1, while the control plots with organic manure showed the slightest reduction. Control plots with straw manure and with second-crop green manure produced the same yields of 1.35 ton/hectare, which corresponded to a yield reduction of $34.5 \%$.

Average potato yields on the control plots were similar to rye yields. In the fallow treatments relative potato yield was $54.7 \%$ lower, while yields on plots receiving organic manure surpassed the average of the treatments by $6.1 \%$. In the controls with straw manure and second-crop green manure, potato yields averaged 7.90 and 7.94 tons/hectare, respectively. The poor yields in the control treatments also direct the attention to the importance of fertilisation. Even various organic matter treatments, included in Westsik's crop rotation, need an adequate level of fertiliser.

Lupine root and green manure treatments: As opposed to the 0.93 ton/hectare average on fallow plots, rye yields in lupine green manure treatments and in lupine root manure treatments averaged 2.44 and 2.17 tons/hectare, respectively. In F-8 crop rotation, where lupine is grown twice within four years, the average yield of rye sown in the second course was 2.62 tons/hectare. In crop rotations F-2 and F-3 potato yields lagged behind the average of the treatments by 9.8 and $17.5 \%$, while rye yields were above the average by 18.4 and $5.3 \%$, respectively. In the F-8 treatment potato produced 12.53 tons/hectare, that is $31.1 \%$ more than the average of the treatments.

Straw manure treatments: The fertiliser, applied to the crop rotation with straw manure, increased rye yields remarkably. The highest yield (2.31 ton/hectare) was achieved when the whole amount of fertiliser was used for feeding the plants. The yield of crop rotation F-6 was $12.1 \%$ higher than the average of the treatments. Fertilisation had lower efficiency and resulted in lower yields if part of the fertiliser was used for the fermentation of straw manure or improving the $\mathrm{C} / \mathrm{N}$ ratio of the incorporated straw. Average rye yield was 2.08 ton/hectare in the former case and $1.87 \mathrm{ton} / \mathrm{hectare}$ in the latter. It means that the F-5 crop rotation yielded $1.0 \%$ more than the average of the treatments while F-4 lagged behind the average by $9.2 \%$. It should be remembered that the amount of organic matter applied is also less in crop rotations F-4. In the crop rotations with straw manure both the actual rye yields and the relative yields (compared to the main average) show an increasing tendency. The only exception is treatment
F-7. Similarly to rye, in straw manure treatment potato yielded most in crop rotations F-5 and F-6. The average yields were 9.89 and 11.72 tons/hectare, respectively, which are 3.5 and $22.1 \%$ more than the average of the treatments.

Fodder crop and farmyard manure treatments: When Vilmos Westsik planned the allocation of various treatments, crop rotations based on fodder crops were placed on areas with more favourable soil conditions. Accordingly, the highest average rye yields were achieved on these sites. Of course, these results are also related the advantageous effect of preceding fodder crops and to the farmyard manure applied in treatments F-10 and F-11. In the average of 69 years, F-11 produced 2.50 ton/hectare rye yield which is above the average of treatments by $21.4 \%$. Similarly high yields were achieved in crop rotations F-9 (2.43 ton/hectare) and F-12 (2.45 ton/hectare). They exceed the average of the treatments by 18.0 and $18.9 \%$.

In the crop rotations based on fodder crops, the average potato yields over 69 years exceeded the average of the treatments. The only exception was treatment F-9, where lupine was included as a green fodder crop. The highest potato yields were achieved in F-11 and F-12. In F-11, which received farmyard manure, the yield was 11.97 ton/hectare, that is by $25.3 \%$ higher than the average of treatments; in F-12, based on rye fodder crop production and green manure production from lupine as a second crop, 11.39 tons/hectare potato yield was harvested which was above the average by $19.2 \%$.

Second crop lupine green manure treatments: The different effects of the crop rotations using lupine green manure from the main or second crop can probably be traced back to the introduction of nitrogen fertilisers. A further difference is that the green manure from second crop lupine was applied before the potato while that one from the main crop lupine was ploughed under before the rye. In crop rotations F-13 and F-14, potato yields exceeded the average of treatments by 13.6 and $9.5 \%$, which means a yield of 10.86 and 10.46 tons/hectare, respectively. Within the treatments including lupine green manure as a second crop considerable difference can be noticed between the fertilised and unfertilised crop rotations. Depending on the time of ploughing under the lupine, the former ones produced 2.20 and 2.18 tons/hectare rye yields, which was 6.8 and $5.8 \%$ more than the average. Based on the data, it can also be stated that ploughing under in the spring is better than in the fall. Yields in F-15 were low but, in the average of 69 years, even this crop rotation produced 0.42 tons/hectare more rye than fallow.

Long-term experiments provide the best practical estimation of sustainability of production on farm scale level. Long-term aspects are essential because many soil properties change slowly over decades and the data from long-term experiments can be used to construct mathematical models. Both rye and potato 
yields changed very little until 1999. The decline in yields in the 1960's was considered to have been caused by the difficulties in controlling weeds, previously controlled by hand hoeing. The same was true for lupine in the 1980's when herbicide resistant weeds caused serious damage and frequently prevented harvest. Then, with the introduction of new potato varieties of high yield potential and also the use of agrochemical and better management techniques to protect plants the yields of both rye and potato increased significantly.

Minimum and maximum yields have varied considerably during the 70 years of the experiment. Analysing the average rye yields of different treatments we can conclude that the poorest results were achieved in 1963, when the mean of the various crop rotations was 1.23 ton/hectare. The highest yields were harvested in 1984 when the average was 3.15 tons/hectare (Figure 1). The difference is $188 \%$. The average yield of potato was the lowest in 1972 and the highest, 12 times as much, in 1991. Rye proved to be the more balanced in productivity. Its yield variations may primarily be attributed to climatic factors while in the case of potato, the variations can be closely related to changes in varieties or in the quality of propagation material.

Figure 1: Differences in rye yield between fallow (F-1) and lupine green manure (F-2) treatments

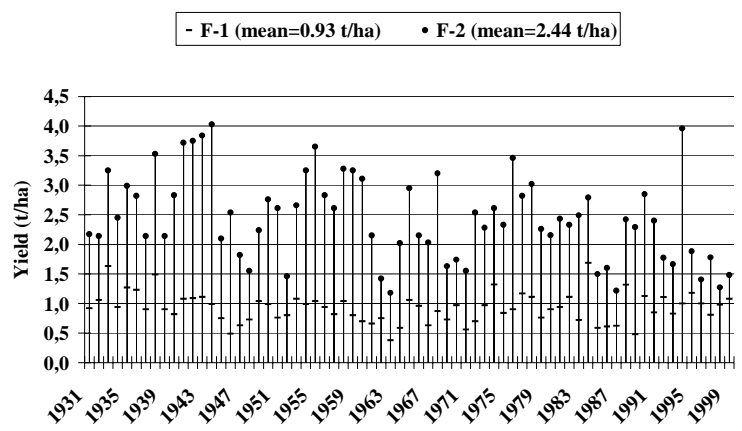

\section{DISCUSSION}

The productivity of soil, as a medium for plant growth, depends greatly on the balance between living and non-living components. The organic matter of the soil serves as a continuous nutrient supply and a factor stabilising the soil's physical environment. To maintain productivity, soluble nutrients removed from soil through plant growth and harvesting must be replaced, either by fertilisers or through biological decomposition of soil organic matter (Katai et al., 1999). For many years, farmyard manure has been the key element in the maintenance of soil fertility (Kemenessy, 1959). Composting manure increases its value, stabilises the nutrients and reduces the risk of environmental pollution. Composted manure provides more stable humus, which improves soil aeration, water infiltration and water holding capacity (Hargitai, 1980; Mandy, 1974). The high temperature of the composting destroys the weeds and reduces water contents.
Although research continues as to how crop rotation influences yields of subsequent crops, farmers can receive maximum benefits from rotating crops, if they know the conditions which influence rotation effects. The reduction of leguminous plants in the cropping system results not only from the availability of fertilisers, but also from the use of fossil energy as a source of power in the agriculture. Because of these changes, farmers are no longer compelled to use one part of their land for the production of forage and grain for their draft animals. There are other benefits of using legumes in the crop rotation, but because of difficulties in quantifying they are often omitted (Lazanyi, 1997a, 1998c). The yields of cereals grown after leguminous crop or in crop rotation are greater than those grown in monoculture regardless of the amount of the fertiliser applied (Johnson, 1969, 1986; Konnecke, 1969). This response is often referred to as the leguminous effect in crop rotation. As additional nitrogen does not eliminate this yield difference much of the response must be due to factors other than nitrogen availability.

Green manure crops play an important role in the regenerative soil conserving strategy. Green manure adds organic matter to the soil, assists in dissolving insoluble nutrients, brings up nutrients from the subsoil and improves the water holding capacity of the soil. The crop rotation system should improve soil condition by including deep rooted plants and plants with a fibrous root system to improve the stability of soil aggregates. Studies have shown that cultivated fallow and monocropping destroy soil structure, increase evaporability and soil compacting (Johnson and Poulton, 1980; Paustian et al., 1992). In turn, by increasing the stability of aggregates, farmers increase water infiltration and retention and thereby not only improve the ability of soil to sustain plants in drought conditions, but help to reduce both wind and water erosion.

Fertilisers combined with organic manure increased yields and soil fertility. The results clearly indicated the benefits though the application of fertilisers (Kadar, 1992). Most of the benefits could be attributed to higher nutrient levels and availability. Yield results showed some benefits for lupine green manure compared to farmyard manure, which could also be explained by the extra nitrogen supplied by this crop and by the higher drought tolerance of crops in green manure and lupine green forage treatments. These benefits from extra organic matter began to be measured after crops with higher yield potential had been introduced and agrochemicals had become available to protect this yield potential through the control of weeds, pests and diseases (Johnson, 1986).

Sustainable land use focuses on the maintenance of soil fertility using alternative methods to develop complex interactions between the biological, chemical and physical properties of the soil. As many aspects of these properties change very slowly over time, long term experiments are required to measure and evaluate their agronomic effects on the environment (Powlson et al., 1992). 
The most important conclusion that can be drawn from the long-term crop rotation experiment is that an optimum soil improving crop rotation can only be developed with due attention to the local natural, economic and entrepreneurial conditions. Similarly, if we want to plan a crop rotation that is appropriate in terms of sustainable farming, we need to perform long-term experiments for the biological demands of both the plants and the soil, we need to know the biological cycle of the organic matter and major plant nutrients, and we have to pay attention to the local features of farm organisation.

\section{REFERENCES}

Fuleky, Gy. (1997): Impact of long-term cropping on chemical properties of soil. In Filep, Gy., (ed) Land Use and Soil Management. Debrecen, 157-169.

Gyorffy, B. (1975): Vetésforgó - Vetésváltás - Monokultúra. Agrártudományi Közlemény, 34. 61-68.

Hargitai, L. (1980): Az intenzív tápanyagellátás és a talaj szervesanyag gazdálkodásának néhány összefüggése. Kertészeti Egyetem Közleményei, Budapest, 44. 61-65.

Johnson, A. E. (1969): Plant nutrients in Broadbulk soils. Rothamsted Experimental Station Report for 1968. Part 2, 93112.

Johnson, A. E. (1986): Soil organic matter, effects on soils and crops. Soil Use and Management, 2. 97-105.

Johnson, A. E.-Poulton, P. R. (1980): Effects of soil organic matter on cereal yields. Rothamsted Experimental Station, Report for 1979. Part 1, 234.

Kadar, I. (1992): A növénytáplálás alapelvei és módszerei. AKAPRINT, Budapest

Katai, J.-Lazanyi， J.-Veres, E. (1999): Talajmikrobiológiai vizsgálatok a Westsik vetésforgó tartamkísérletben. Tiszántúli Mezőgazdasági Tudományos Napok, Debrecen, 169-175.

Kemenessy, E. (1959): Talajerögazdálkodás. Akadémiai Kiadó, Budapest

Konnecke, G. (1969): Vetésforgók. Mezőgazdasági Könyvkiadó, Budapest

Lazanyi, J. (1994): Homokjavító vetésforgókkal végzett kísérletek eredményei. DATE Kutató Központ, Nyíregyháza, 1-238.

Lazanyi, J. (1995a): Alternatív tápanyaggazdálkodás a Westsik vetésforgó-kísérlet tapasztalatai alapján. Agrokémia és Talajtan, 44. 307-316.

Lazanyi, J. (1995b): Results of Sustainable Production in Westsik's Crop Rotation Experiment. Communication of the Scientific Body of the Hungarian Academy of Sciences. Nyíregyháza, 1-172.

Lazanyi, J. (1996): Results of Westsik's crop rotation experiment for sustainbale agriculture. Hungarian Agricultural Research, 5. 1. 4-8.

Lazanyi, J. (1997a): Linking conventional and sustainable agriculture. In Filep, Gy., (ed) Land Use and Soil Management, Debrecen, 68-86.

Lazanyi, J. (1997b): Homoki gazdálkodás a Westsik-féle vetésforgó kísérlet tükrében. Homoktalajok hasznosításának időszerü kérdései a hazai homok-kutatások tükrében. Kecskemét, 76-84.

Lazanyi, J. (1998a): Sustainable production in Westsik's crop rotation experiment Second Balkan Symposium. Novi Sad., $321-324$.
Lazanyi, J. (1998b): Linking environment and agriculture in Westsik's crop rotation experiment. International Symposium on Agroecology. Regional Research Institute of Agroecology, Michalovce, 137-151.

Lazanyi, J. (1998c): Ecological impact of long-term crop rotation. Second Hungarian-Egyptian Conference on Environment, Budapest

Lazanyi, J. (1998d): Principles of Sustainable Agriculture in Nyírség Region. Lazanyi, J., (ed) Use of alternative crops for forage production and soil conservation. Nyíregyháza, 149162.

Lazanyi, J. (1999): Nutrient management in Westsik's crop rotation experiment. Tiszántúli Mezőgazdasági Tudományos Napok, Debrecen, 31-37.

Lazanyi, J. (1999b): Fenntartható talajhasználat a Westsik vetésforgó kísérlet tapasztalatai alapján. Növénytermesztési Tudományos Nap, Budapest, 33.

Lazanyi, J. (1999c): Westsik's crop rotation experiment. In: Lazanyi, J.-Dobranszki, J. (ed.) Agricultural Research in Nyírség Region. Nyíregyháza, 131-168.

Lazanyi, J. (1999d): Principles of sustainable agriculture in Nyírség region. In: Lazanyi, J.-Dobranszki, J. (ed.) Agricultural Research in Nyírség Region. Nyíregyháza, 169193.

Lockeretz, W. (1988): Open questions in sustainable agriculture, American Journal of Alternative Agriculture, 3. 174-181.

Mandy, Gy. (1974): A bő termés biológiai alapjai. Mezőgazdasági Kiadó, Budapest

Paustian, K.-Parton, W. J.-Persson, J. (1992): Modeling soil organic matter in organic-amended and nitrogen-fertilized long-term plots. Soil Sci. Soc. Am. J., 56. 476-488.

Pepo, P.-Nagy, J. (1997): Sustainable land use in Trans-Tisza region. In Filep, Gy., (ed) Land Use and Soil Management, Debrecen, 34-56.

Powlson, D. S.-Hart, P. B. S.-Poulton, P. R.-Johnson, A. E.Jenkinson, D. S. (1992): Influence of soil type, crop management and weather on the recovery of N-labelled fertilizer applied to winter wheat in spring. Journal of Agricultural Science, Cambridge, 118. 83-100.

Varallyay, Gy. (1989): Soil degradation processes and their control in Hungary. Land degradation and rehabilitation, 1. 171-188.

Westsik, V. (1951): Homoki vetésforgókkal végzett kísérletek eredményei. Mezőgazdasági Kiadó, Budapest

Westsik, V. (1965): Vetésforgó kísérletek homoktalajon. Akadémiai Kiadó, Budapest 